\title{
Identifying creative thinking skills in subject matter bio-chemistry
}

\author{
M. Dwi Wiwik Ernawati ${ }^{1}$, Damris Muhammad ${ }^{2}$, Asrial Asrial ${ }^{3}$, Muhaimin Muhaimin ${ }^{4}$ \\ ${ }^{1}$ Postgraduate Program, Universitas Jambi, Indonesia \\ ${ }^{2,3,4}$ Faculty of Teaching amd Education, Universitas Jambi, Indonesia
}

\begin{abstract}
Article Info
Article history:

Received Jul 23, 2019

Revised Sep 30, 2019

Accepted Nov 30, 2019

\section{Keywords:}

Creative thinking

Elaboration

Flexibility

Fluency

Originality

Sensitivity

ABSTRACT

Creative thinking is needed in 21 st century learning. This quantitative study aimed to determine whether chemistry education students at Universitas Jambi have the initial ability of creative thinking. The type of research that is used is a research design survey that is strengthened by the results of interviews to support the results of quantitative data. Where the number of all samples from this study was 188 college students with details of 140 female and 48 male college students from 4 th semester chemistry education students who were taken based on purposive sampling technique. Data were then analyzed using SPSS 21 application to find descriptive statistics in the form of mean, median, min, max, and category. From the results of the analysis conducted, it was found that there were students' creative thinking abilities in chemistry subjects in bio-chemical material indicated by sensitivity indicators which had a good category of $44.7 \%$ (84 of 188), fluency indicators had a good category of $41.5 \%$ (78 of 188), the flexibility indicator has a good category of $40.4 \%$ (76 of 188), the originality indicator has a category of $43.1 \%$ ( 81 of 188), and the elaboration indicator has a category of $39.4 \%$ (74 of 188 ).
\end{abstract}

Copyright (c) 2019 Institute of Advanced Engineering and Science. All rights reserved.

Corresponding Author:

M. Dwi Wiwik Ernawati,

Postgraduate Program,

Universitas Jambi,

Jambi-Muara Bulian Street, KM. 15, Jambi, 36361, Indonesia

Email: ernawatiwiwik88@gmail.com

\section{INTRODUCTION}

Education is something very important to do. It is intended to be productive, creative, innovative, and effective generations through the integration of attitudes, abilities, and knowledge with life skills [1-4]. Therefore education institutions in the country establish competencies as goals of the curriculum [5, 6]. In addition, lecturer education practitioners agree that teacher education aims to educate high-quality teachers who will be successfully integrated into the education system [7-9] The future global competencies of school teachers are expected to include the knowledge base, skills, and attitudes they need to effectively carry out their professional duties in schools and function profitably in changing and interdependent societies [10]. Therefore, since the lecture bench, all students are required to cooperate with their surrounding colleagues. With this, students must have a good attitude in order to work with their partners [11].

In learning, attitude is also an aspect that deserves to be taken into account. In the learning process, especially in chemistry lessons, participants' attitudes are important to reject [12]. The attitudes of the process are very important $[13,14]$. Because, students who have this view will have different attitudes, with students who have a positive outlook during the learning process [15]. In learning cognitive and affective aspects are needed because students who have high affective will make these students find self-concept, critical and creative from a student. Attitudes can be defined as a tendency to provide learned, consistent, positive or negative reactions to an object [12-16]; define attitude as part of individual personality influenced by 
relationship behavior with it. Attitudes can also be defined as a tendency to act against people, things, events, or ideas. Attitudes seem unconscious, sustainable and closely related to opinion. Attitudes are formed as a result of learning experiences that will foster the interest and skills of a student. Understanding student attitudes are very important in supporting the achievements, interests, and abilities of students in certain subjects. Akey, T. M. [17] agreed that the attitude of secondary school students can contribute to their academic achievement. It has been observed that many students today lose interest in science subjects such as chemistry. This is worrying because future generations need a good future community in science such as chemistry [18].

Students must have good attitude. The student must also have process skills within the student. [19], Determines process skills as skills that facilitate learning, means of research and active learning, develop a sense of individual responsibility when learning, and enhance the permanence of knowledge. [20] Using the term 'process skills' to refer to the processing strategies that a person is responsible for solving a problem. [21] They are things that scientists do when they study and investigate. Process skills are needed in solving problems that will make the student have creative thinking skills. Because teachers must have science process skills, it is a skill used by scientists when conducting scientific investigations [22-24] states that having critical and creative abilities are needed in this rapidly changing, complex, and full of information world so that individuals can live happily and successfully.

From that, the current curriculum also emphasizes the ability of students to think creatively. Although creative thinking includes cognitive and affective elements like other ways of thinking, it mainly involves the use of cognitive processes [25]. Because chemistry lessons focus on training thinking and reasoning, developing creative activities, developing problem solving skills and communicating ideas. Creative thinking skills are inherently normative cognitive functioning rather than innate available to only a few talents [26, 27]. Importantly, various behavioral studies have been shown that creative thinking skills can be enhanced [28-36]. Efforts can be seen in terms of material, learning processes, improvement and support of infrastructure, increasing the ability of teachers to teach through upgrading or training, reducing or sharing material into more parts. Simple (simplifying material content in the curriculum) or improving the quality of input (students) at school. Scientists, Teachers, and engineers cannot solely rely on their technological knowledge but will also have skills in areas such as problem solving, creative thinking, written and oral communication and teamwork [37-39]. The approach to addressing this problem, researchers put more emphasis on the learning process, because the process is the daily duty and professional responsibility of teachers and will have an impact on the tasks in the next class. When referring to the identification of the causes of these weaknesses, the learning process requires a way that encourages students to understand problems, increases students' creative thinking skills in developing settlement plans and engages students actively in finding problems themselves, and encourages student-teacher learning only as a facilitator.

The lack of motivation and high school thinking and the lack of motivation and interest to learn, especially in the subjects of science, is becoming a more common reality nowadays [40]. In the context of learning, previous researcher [37] stated that creative thinking skills are closely related to how to teach teachers in schools. In the sense that the teacher becomes the main actor in the school and parents become determinants in the home and the environment in fostering children's creativity. But the reality in the field shows that learning carried out by teachers, especially chemistry teachers, still applies the old paradigm of the dimensions of cognitive processes. In this case, in learning the teacher still relies on six processes, namely: memory, understanding, application, analysis, synthesis, and evaluation. Lynch etc [39] argues that the definition of mathematical creativity built in the western world is as a process that opens new doors, unusual and in-depth knowledge/understanding built through problem solving, while in the view of the eastern world creativity focuses on reinterpreting a problem which is viewed from a different angle. The definition of creativity proposed by [25] is a certain domain thinking process used by chemists when they solve irregular chemical problems.

Creative thinking skills in all domains, including science, technology, medicine, and art arise from the basic mental operation of different things whose concepts are mixed because creative ideas are always a new combination of old ideas [39]. Cognitive abilities that include mastery of concepts and scientific facts in chemistry learning also need to be trained as a basis for training students' creative thinking skills [41]. Thinking ability is categorized on basic thinking skills and complex thinking skills [25]. Basic thinking ability includes basic processes (basic processes) which are a picture of rational thinking processes that contain a set of mental processes from the simple to the complex. The process of basic thinking skills includes causation, transformation, relationships, classifications, and qualifications. The ability to think complex is the ability to think based on basic thinking processes. Preseissen in [25] states that there are at least four complex thought processes that occur in a person, namely problem solving, decision making, critical thinking, and creative thinking. This thinking ability is important for every student, both at school and in everyday life. By having good thinking skills, students will have the capital to be able to solve problems 
that occur in their lives. Having the ability to think, or the ability to think skillfully according to [41] can build personal democratic individuals. The purpose of this study was to determine the initial ability of creative thinking in the Bio-Chemistry course.

\section{RESEARCH METHOD}

\subsection{Research design}

The research design used by researchers is quantitative research that uses the research design is survey research. Survey research is a procedure in quantitative research where researchers administer surveys to a sample or to the entire population used to describe population attitudes, opinions, behaviors, or special characteristics $[42,43]$. The design of this study was applied because it was in accordance with the objectives of the study, where the aim was to find out the Attitudes of High School Students to the Subjects of Physics.

\subsection{Research subject}

The research sample was obtained from 188 jambi university chemical education students who had been in semester 4th (four) who used a purposive sampling technique with details of 140 female students and 48 male students. Purposive sampling is a sampling technique based on the criteria of the researcher [44]. The criteria that the researcher intends is that the student is in the $4^{\text {th }}$ semester

\subsection{Research instrument}

In this study, the study used questionnaire instruments and interviews. The questionnaire creative thinking has 16 valid statements with 5 indicator that using a Likert scale 4 (five) for positive statements Strongly Disagree having a score of 1, Disagree having a score of 2, Agree has a score of 3 and Strongly Agree 4. For negative statements Strongly Disagree has a score of 4, Disagree has a score of 3, a score of 2 and Strongly Agree has a score of 1 and using structured interviews aimed at strengthening quantitative data. The data used by the SPSS program to look for descriptive and inferential statistics. Descriptive statistics are presented in a summary frequency, for example, mode, mean, median, minimum, maximum and standard deviation [45]. The categories of creative thinking questionnaires include, very good, good, not good, and very not good, as shown in Table 1.

Table 1. Categories of creative thinking

\begin{tabular}{lccccc}
\hline \multicolumn{1}{c}{ Category } & & \multicolumn{4}{c}{ Interval } \\
& Sensitivity & Fluency & Flexibility & Originality & Elaboration \\
\hline Very Not Good & $3.0-5.25$ & $3.0-5.25$ & $3.0-5.25$ & $3.0-5.25$ & $4.0-7.0$ \\
Not Good & $5.26-7.5$ & $5.26-7.5$ & $5.26-7.5$ & $5.26-7.5$ & $8.0-10.0$ \\
Good & $7.6-9.75$ & $7.6-9.75$ & $7.6-9.75$ & $7.6-9.75$ & $11.0-13.0$ \\
Very Good & $9.76-12.0$ & $9.76-12.0$ & $9.76-12.0$ & $9.76-12.0$ & $14.0-16.0$ \\
\hline
\end{tabular}

\subsection{Analysis data}

All data were obtained from creative thinking questionnaires collected and calculated and assisted with the SPSS 21 application. In this study, quantitative data were analyzed using Mean, Median, Min, Max, and Percentage. Descriptive statistics are given to calculate the frequency, percentage, mean, median, min, and max of sample [43]; followed by interviews that are used to strengthen the results of quantitative data; followed by interviews intended to strengthen the results of quantitative data. The steps in the interview can be seen as follows: (1) the ideas, themes, pieces of data and words. (2) Pay attention to patterns and themes. (3) Try to make good data, using intuition to reach conclusion. (4) Is a group set items into categories, types, behavior, and classification? (5) Makes a metaphor that uses figurative language and connotative rather than literal and denotative language, animates data, reducing data, making patterns, aligning data, linking data with theory. (6) Separate variables to decipher, differentiate and 'unpack' ideas, ie move from drive to integration and obfuscate data. (7) Surrendered specifically into the general, large number of variables under a small number of (frequently) unobserved hypothetical variables. (8) Identifies and records relationships between variables. (9) Finds an intervening variable: looks for another variable that seems to be a 'block' calculation for what is expected to be a strong relationship between variables. (10) The logical chain of evidence building: noting causality and making conclusions. (11) Creating conceptual/theoretical coherence: moving from a method to construct stories to explain phenomena [45]. 


\section{RESULTS AND DISCUSSION}

College students can be seen from the characteristics they have, feeling happy, or just normal from students in solving problems when they study. Besides that, it can also be seen from feeling happy, unhappy, like it or not, motivated or not motivated, interested or not from the college student. Attitude is a term that reflects the pleasure, displeasure, or ordinary feelings of someone towards something [12]. And the attitude and process skills possessed by college students are able to foster students' creative thinking skills. College students' creative thinking skills are very important to have in all aspects of educational studies [46]. Where, in this study, what will be examined are college student sensitivity, fluency, flexibility, originality, and elaboration of creative thinking skills.

\subsection{Sensitivity}

The results of the creative thinking questionnaire given and obtained and processed using the SPSS 21 application can be seen in the Table 2 .

Table 2. The result of indicator sensitivity in creative thinking

\begin{tabular}{|c|c|c|c|c|c|c|c|c|c|}
\hline \multirow[b]{2}{*}{ Range } & \multicolumn{4}{|c|}{ Classification } & \multirow[t]{2}{*}{ Mean } & \multirow[t]{2}{*}{ Median } & \multirow[t]{2}{*}{ Min } & \multirow[t]{2}{*}{ Max } & \multirow[t]{2}{*}{$\%$} \\
\hline & M & $\mathrm{F}$ & Interest & Total & & & & & \\
\hline $3.0-5.25$ & 5 & 22 & Not very good & 27 & & & & & 14.4 \\
\hline $5.26-7.5$ & 9 & 35 & Not good & 44 & & & & & 23.4 \\
\hline $7.6-9.25$ & 24 & 60 & Good & 84 & 7.8 & 8.0 & 4.00 & 11.00 & 44.7 \\
\hline $9.26-12.0$ & 10 & 23 & Very good & 33 & & & & & 17.5 \\
\hline TOTAL & 48 & 140 & & 188 & & & & & 100 \\
\hline
\end{tabular}

Table 2 shows distribution of the students' creative thinking skill of 188 respondents. About 33 students have very good creative thingking skill but majority of the students are at good (44.7\%). This can also be seen from the results of interviews that have been conducted.

"When the biochemistry lecture is going on, what do you do?"

"I pay attention to what is explained in the lecture"

"When you pay attention and are asked by lecturers about what biochemistry lectures do you do?"

"I answered the lecturer's question according to what was asked, as we know the benefits of protein in our body"

Sensitivity skills are student skills in detecting, recognizing, understanding and responding to a problem or phenomenon. Students who have this ability can identify, recognize and detect a phenomenon, find problems and patterns of problems produced. In addition, students also experience learning that has meaning, by observing making students feel very useful for fulfilling their curiosity [47, 48]. So that the learning process has a high meaning. Where students are required to be sensitive to a phenomenon and find problems and ask questions of these problems which later can re-explain the meaning of the statement [49]. When students are given the opportunity to ask questions, students' creativity will develop. At the stage of trying students experience a different process than usual. Namely, students are required to design their own experiments. Students are given the opportunity to develop their creativity in designing experiments.

\subsection{Fluency}

The results of data creative thinking analysis are given in Table 3. Of 188 respondents consisted with 19 male students and 59 women students are most categorized as good (41.5\%).

Table 3. The result of indicator fluency in creative thinking

\begin{tabular}{|c|c|c|c|c|c|c|c|c|c|}
\hline \multirow[b]{2}{*}{ Range } & \multicolumn{4}{|c|}{ Classification } & \multirow{2}{*}{ Mean } & \multirow[t]{2}{*}{ Median } & \multirow[t]{2}{*}{ Min } & \multirow[t]{2}{*}{$\operatorname{Max}$} & \multirow[t]{2}{*}{$\%$} \\
\hline & M & $\mathrm{F}$ & Interest & Total & & & & & \\
\hline $3.0-5.25$ & 8 & 17 & Not very good & 25 & \multirow{5}{*}{8.3} & \multirow{5}{*}{8.00} & \multirow{5}{*}{3.00} & \multirow{5}{*}{10.00} & 13.3 \\
\hline $5.26-7.5$ & 12 & 34 & Not good & 46 & & & & & 24.5 \\
\hline $7.6-9.25$ & 19 & 59 & Good & 78 & & & & & 41.5 \\
\hline $9.26-12.0$ & 9 & 30 & Very good & 39 & & & & & 20.7 \\
\hline TOTAL & 48 & 140 & & 188 & & & & & 100 \\
\hline
\end{tabular}

The results of the questionnaire analysis in Table 3, the indicator of fluency in creative thinking in Jambi University chemistry education has good fluency ability of $41.5 \%$ (78 out of 188) in students in biochemical subjects. This ability is shown by the way students give a lot of ideas in a problem when learning 
takes place; this is because the student has good fluency abilities. This fact can also be seen from the results of interviews that have been conducted.

"When you are given a problem when biochemical lectures in a group, what will you do?"

"I will give my input or ideas so that the problems can be resolved"

"When you are given a task and given a deadline in biochemical lectures, what will you do?"

"I do the task faster and do more than other children"

Fluency indicators in the ability to think creatively are related to the number of ideas or answers produced by students. Fluency in creative thinking can be seen from the number of problems given and given answers to the problem [50-54]; which will later involve students actively to carry out activities to explore problems to develop various problem-solving ideas. That makes this research work with Fluency indicated by the ability to produce a large number of ideas to solve problems smoothly and precisely and find different and extraordinary ideas to solve a problem [55].

\subsection{Flexibility}

Table 4 shows the results of data nalaysis of creative thinking questionnaire. Of 188 respondents 23 male students categorized good and 53 wamen students is good. Flexibility of creative thinking of 76 students $(40.4 \%)$ is good categorized.

Table 4. The result of indicator flexibility in creative thinking

\begin{tabular}{|c|c|c|c|c|c|c|c|c|c|}
\hline \multirow[b]{2}{*}{ Range } & \multicolumn{4}{|c|}{ Classification } & \multirow[t]{2}{*}{ Mean } & \multirow[t]{2}{*}{ Median } & \multirow[t]{2}{*}{ Min } & \multirow[t]{2}{*}{ Max } & \multirow[t]{2}{*}{$\%$} \\
\hline & $\mathrm{M}$ & $\mathrm{F}$ & Interest & Total & & & & & \\
\hline $3.0-5.25$ & 4 & 24 & Not very good & 28 & & & & & 14.9 \\
\hline $5.26-7.5$ & 13 & 35 & Not good & 48 & & & & & 25.4 \\
\hline $7.6-9.25$ & 23 & 53 & Good & 76 & 8.7 & 8.00 & 4.00 & 11.00 & 40.4 \\
\hline $9.26-12.0$ & 8 & 28 & Very good & 36 & & & & & 19.3 \\
\hline TOTAL & 48 & 140 & & 188 & & & & & 100 \\
\hline
\end{tabular}

The results of the questionnaire analysis in Table 4, the indicators of flexibility in creative thinking at Jambi University's chemistry education have good flexibility ability of 40.4\% (76 out of 188) students in the biochemistry course. This ability is shown by the way students provide answers when learning takes place because of having good flexibility. This can also be seen from the results of interviews that have been conducted.

"When you are given a question in a biochemical lecture, what will you do?"

"I will answer the questions from the biochemistry lecture using my own method or the method that has been given, in other words, I want to find answers to others using different methods, which will prove that my answer is correct"

Based on the results of the interviews conducted, it was found that students have the ability to solve problems in different ways. That indicates that the student has good flexibility. Students who have flexibility in solving problems if they can solve questions in two or more different ways and are right and easily move from certain types of thinking to other types of thinking. Indicators of flexibility in the ability to think creatively are related to the number of ideas or answers produced, not only have many answers, but the answers must vary [56]. This can be seen from the way students solve problems in the initial study. Actually, students have been able to produce more than one answer, but the answers they put forth come from the same or less varied concepts. Students have the freedom to develop problem-solving strategies so that various strategies are obtained [57, 58]. During learning, not all groups are able to provide more than one varied strategy. But this deficiency can be supplemented by group discussions because there is an opportunity for groups with different strategies to express their opinions so that various strategies emerge which can later present a concept in different ways that show student creativity [54-59].

\subsection{Originality}

Table 5 reveals originality of creative thinking skill. About 21 male students and 60 wamen students are majority good category.

Table 5. The result of indicator originality in creative thinking

\begin{tabular}{|c|c|c|c|c|c|c|c|c|c|}
\hline \multirow[b]{2}{*}{ Range } & \multicolumn{4}{|c|}{ Classification } & \multirow[t]{2}{*}{ Mean } & \multirow[t]{2}{*}{ Median } & \multirow[t]{2}{*}{ Min } & \multirow[t]{2}{*}{$\operatorname{Max}$} & \multirow[t]{2}{*}{$\%$} \\
\hline & M & $\mathrm{F}$ & Interest & Total & & & & & \\
\hline $3.0-5.25$ & 6 & 21 & Not very good & 27 & \multirow{5}{*}{8.1} & \multirow{5}{*}{8.00} & \multirow{5}{*}{4.00} & \multirow{5}{*}{10.00} & 14.4 \\
\hline $5.26-7.5$ & 12 & 36 & Not good & 48 & & & & & 25.5 \\
\hline $7.6-9.25$ & 21 & 60 & Good & 81 & & & & & 43.1 \\
\hline $9.26-12.0$ & 9 & 23 & Very good & 32 & & & & & 17.0 \\
\hline TOTAL & 48 & 140 & & 188 & & & & & 100 \\
\hline
\end{tabular}

Identifying creative thinking skills in subject matter bio-chemistry (M. Dwi Wiwik Ernawati) 
The results of the analysis of the questionnaire in Table 5, indicators of originality in creative thinking in the chemistry education of Jambi University had a good originality ability of $43.1 \%$ ( 81 out of 188) students in the bio-chemical eye. This ability is shown by thinking in new ways or with unique expressions, and the ability to produce unusual thoughts rather than thoughts that are clearly known due to having good originality abilities. This can also be seen from the results of interviews that have been conducted.

"When in a discussion on biochemical lectures, what ideas did you give in the group?"

"I give a relatively new idea in solving problems or answers that are different from the usual"

Originality refers to the ability to produce unpredictable ideas. Teaching students to find and think in a general way and explore a problem will foster new ideas or ways of thinking from that individual $[60,61]$. Therefore, originality is related to the authenticity or unique answers of students with how rarely an idea is produced. Most students still solve problems in a way that is often used, namely the way that is obtained during learning. However, some students have been able to find ways of solving that are different from the concepts obtained when learning comes from other concepts or comes from the experience that has passed.

\subsection{Elaboration}

Table 6 shows student elaboration in creative thinking skill. The table explains that majority of students are in good category.

Table 6. The result of indicator elaboration in creative thinking

\begin{tabular}{|c|c|c|c|c|c|c|c|c|c|}
\hline \multirow[b]{2}{*}{ Range } & \multicolumn{4}{|c|}{ Classification } & \multirow[t]{2}{*}{ Mean } & \multirow[t]{2}{*}{ Median } & \multirow[t]{2}{*}{ Min } & \multirow[t]{2}{*}{ Max } & \multirow[t]{2}{*}{$\%$} \\
\hline & $\mathrm{M}$ & $\mathrm{F}$ & Interest & Total & & & & & \\
\hline $4.0-7.0$ & 6 & 23 & Not very good & 29 & \multirow{5}{*}{12.0} & \multirow{5}{*}{13.00} & \multirow{5}{*}{6.00} & \multirow{5}{*}{15.00} & 15.4 \\
\hline $8.0-10.0$ & 13 & 40 & Not good & 53 & & & & & 28.2 \\
\hline $11.0-13.0$ & 19 & 55 & Good & 74 & & & & & 39.4 \\
\hline $14.0-16.0$ & 10 & 22 & Very good & 32 & & & & & 17.0 \\
\hline TOTAL & 48 & 140 & & 188 & & & & & 100 \\
\hline
\end{tabular}

The results of the questionnaire analysis in Table 6; indicators of elaboration in creative thinking in Jambi University chemistry education have good elaboration ability of $39.4 \%$ (74 out of 188) students in chemistry subjects. This ability is shown by explaining something in detail rather than other people because it has good elaboration skills. This can also be seen from the results of interviews that have been conducted.

"When your friend can't explain a problem in a biochemical lecture, what action do you take?"

"I will examine the problem in more detail than my friend did so that I get the answer I want"

"When your friend explains something from a problem that he encountered, what will you do?"

"I will add, clarify or elaborate more deeply so that the problem can be answered"

Details/elaboration is the ability to explain, develop, enrich or describe in more detail the answers or ideas given. By having this ability students can answer the problems that have been given [62-64]. Students who have this ability will also have good grades because they will help their friends in enriching ideas that are owned by others.

Creative and critical thinking is very important for students in all aspects of educational studies [65]. Being creative is a universal human attribute. However, representation of creative abilities will have both local and global cultural influences [66, 67]. Design training is to help students gain creative achievements through developing their integrative abilities in comparison, analysis, and imagination.

Evaluation of student learning behavior and learning outcomes helps to understand student learning characteristics, interests, and learning achievements. It also determines the effectiveness of their learning and to propose additional teaching based on diagnosis, to develop creativity and encourage learning motives [68, 69].

Creative personalities dare to engage in uncertain and ambiguous situations, find new aspects in something that is fun and familiar and create new experiences, always eager to look for new styles and behaviors and continue with various stages of the creative process [65-71]. Characteristics of creativity are defined as recognizing one's own unity and coherence and evaluating conditions to unite the knowledge that people use within this framework of awareness, understand information obtained through observation and experimentation, and make it ready to use, understand problems very quickly and make decisions quickly link them with his imagination [72-73]. 


\section{CONCLUSION}

The current research found that there was the ability of creative thinking of students in chemistry subjects in bio-chemical material less than 50 percent are in good category. For this reason, it is recommended that students need to be given the opportunity to develop direct experiences and thoughts in learning activities. Teachers must use learning strategies to develop various abilities in learning.

\section{ACKNOWLEDGEMENTS}

The researcher would like to thank the Chair of the Chemistry Education Study Program, the head of the PMIPA Department, and the Teacher and Education Faculty Dean who gave me the opportunity and time to do my research on chemistry education students and all 4th semester students who have helped me, as well as all, have been in touch during the making of this article, I want to say thank you.

\section{REFERENCES}

[1] Andrini, V. S., "The effectiveness of inquiry learning method to enhance students' learning outcome: A theoritical and empirical review," Journal of Education and Practice, vol. 7(3), pp. 38-42, 2016. https://eric.ed.gov/?id=EJ1089825

[2] Kabeel, A. R., \& Eisa, S. A.-M., "The correlation of critical thinking disposition and approaches to learning among baccalaureate nursing student," Journal of Education and Practice, vol. 7(32), pp. 91-103, 2016. https://eric.ed.gov/?id=EJ1122541

[3] Taghva, F., Rezael, N., Ghaderi, J., \& Taghva, R., "Studying the relationship between critical thinking skills and students' educational achievement (Eghlid Universities as case study)," International Letters of Social and Humanistic Sciences, vol. 25, pp. 18-25. 2014. https://doi.org/10.18052/www.scipress.com/ILSHS.25.18

[4] Siburian, J., Corebima, A. D., Ibrohim, \& Saptasari, M., "The correlation between critical and creative thinking skill on cognitive learning results," Eurasian Journal of Educational Research, vol. 81, pp. 99-114, 2019. https://doi.org/10.14689/ejer.2019.81.6

[5] Pantic, N \& Wubbels, T., "Competence-based teacher eduation: A change from Didaktik to Curriculum culture," Journal of Curriculum Studies, vol. 44(1), pp. 61-87, 2012. https://doi.org/10.1080/00220272.2011.620633

[6] Unlu, Sahika, "Curriculum development study for teacher education supporting critical thinking," Eurasia Journal Educational Research, vol. 76, pp. 165-186. 2018. https://doi.org/10.14689/ejer.2018.76.9

[7] Ezer, H., Gilat, I \& Sagee, R., "Perception of teacher education and professional identity among novice teachers," European Journal of Teacher Education, vol. 33(4), pp. 391-404, 2010. https://doi.org/10.1080/02619768.2010.504949

[8] Boonjeam W., Tesaputa K., \& Sri-ampai A, "Program development for primary school teachers' critical thinking," International Education Studies, vol. 10(2), pp. 131-138, 2017. http://dx.doi.org/10.5539/ies.v10n2p131

[9] Dobber, M., Vandyck, I., Akkerman, S, Graaff, D, R, Beishuizen, J., Pilot, A., Verloop, N \& Vermunt, J., "The development of community competence in the teacher education curriculum. European Journal of Teacher Education", vol. 36(3), pp. 346-363, 2013. http://dx.doi.org/10.1080/02619768.2012.718326

[10] Signagatullin, I. M., "Developing preservice elementary teachers' global competence," International Journal of Educational. Vol. 28(1), pp. 48-62, 2019. https://doi.org/10.1177/1056787918824193

[11] Astalini, Kurniawan, D. A., Perdana, R., \& Pathoni, H., "Identification of students' attitudes towards physics in the 5 High School, Jambi City (in bahasa)," Unnes Physics Education Journal, vol. 8(1), pp. 34-43, 2019. https://doi.org/10.15294/upej.v8i1.29510

[12] Astalini, Kurniawan, D. A., Darmaji, Sitorus, L. R., Perdana, R., "characteristic of students attitude to physics in muaro jambi high school, Humanities \& Social Science Reviews," vol. 7(2), pp. 91-99, 2019. https://doi.org/1018510/hssr.2019.7210

[13] Kurniawan, D, A., Astalini, \& Anggraini, L., " Evaluation of Junior high school attitude towards natural sciences in Muaro Jambi Regency (in bahasa)," Jurnal Ilmiah Didaktika: Media Ilmiah Pendidikan dan Pengajaran, vol. 19(1), pp. 123-139, 2018. http://dx.doi.org/10.22373/jid.v19i1.4198

[14] Astalini, Kurniawan, D. A., Perdana, R., \& Kurniasari, D., "Identification of student attitudes toward physics learning at Batanghari district high school," The Educational Review, USA, vol. 2(9), pp. 475-484, 2018. http://dx.doi.org/10.26855/er.2018.09.003

[15] Astalini, Kurniawan, D. A., Perdana, R., \& Kurniawan, W., "Identification attitudes of learners on physics subject," EST Journal of Educational Science and Technology, vol. 5(1), pp. 39-48, 2019. https://doi.org/10.26858/est.v5i1.8231

[16] Bulunuz, Mizrap, "The role of playful science in developing positive attitudes towards teaching science in a science teacher preparation program," Eurasian Journal Educational Research, vol. 58, pp. 67-88, 2015. http://dx.doi.org/10.14689/ejer.2014.58.2

[17] Akey, T. M., "School context, student attitudes and behavior, and academic achievement: An exploratory analysis," MDRC, 2006. https://files.eric.ed.gov/fulltext/ED489760.pdf

[18] Yunuz, F. W., \& Ali, Z. M., "Urban students' attitude towards learning chemistry. procedia-social and behaviorial sciences," vol. 68, pp. 295-304, 2012, https://doi.org/10.1016/j.sbspro.2012.12.228 
[19] Dogan, I., \& Kunt, H., "Determination of prospective preschool teachers' science process skills," Journal of European Education, vol. 6(1), pp. 8-18, 2017, https://doi.org/10.18656/jee.65104

[20] Behera, S., Dr. C.V. Satyaprakasha., "Effectiveness of multi media teaching on process skill in biology," International Journal of Informative \&Futuristic Research, vol. 1(8), 2014.

[21] Sagala, N. L., Rahmatsyah, Mariati, P. S., "The influence of problem based learning model on scientific process skill and problem solving ability of student," IOSR-J RME, vol. 7(4), 2017, https://doi.org/10.9790/73880704040109

[22] Mutisya, S. M., Rotich, S., \& Rotich, P. K., "Conceptual understanding of science process skills and gender stereotyping: a critical component for inquiry teaching of science in Kenya' S Primary fSchools," Asian Journal of Social Sciences and Humanities, vol. 2(3), pp. 359-369, 2013, Http://Hdl.Handle.Net/123456789/6791

[23] Darmaji, Kurniawan, D. A., Parasdila, H., \& Irdianti, "Description of science process skills' physics education students at Jambi University in temperature and heat materials," The Educational Review, USA vol. 2(9): 485-498, 2018. http://dx.doi.org/10.26855/er.2018.09.004

[24] Wall, T. F., "The transferability of higher order cognitive skills," Procedia-Social and Behaviorial Science, vol. 174, pp. 233-238, 2015, https://doi.org/10.1016/j.sbspro.2015.01.652

[25] Bacanli, H., Dombayci, M. A., Demir, M., \& Tarhan, S., "Quadruple thinking: Creative thinking," Procedia Social and Behavioral Science, vol. 12, pp. 536-544, 2011, https://doi.org/10.1016/j.sbspro.2011.02.065

[26] Ward, T.B., Smith, S.M., Finke, R.A., "Creative cognition. In: Sternberg, R.J. (Ed.), Handbook of Creativity," Cambridge University Press, Cambridge, pp. 189-212, 1999.

[27] Colzato, L. S., Ritter, S. M., \& Steenbergen, L., "Transcutaneous vagus nerve stimulation (tVNS) enhances divergent thinking," Neuropsychologia, vol. 111, pp. 72-76, 2018, https://doi.org/10.1016/j.neuropsychologia.2018.01.003

[28] Baas, M., Nevicka, B., \& Ten Velden, F. S, "Specific mindfulness skills differentially predict creative performance. Personal," Social. Psychol. Bull, vol. 40(9), pp. 1092-1106, 2014, https://doi.org/10.1177/0146167214535813

[29] Colzato, L.S., Ozturk, A., \& Hommel, B., "Meditate to create: The impact of focusedattention and open monitoring training on convergent and divergent thinking," Front. Psychol, vol. 3, pp. 116, 2012, https://doi.org/10.3389/fpsyg.2012.00116

[30] Colzato, L.S., Szapora, A., Pannekoek, J.N., \& Hommel, B., "The impact of physical exercise on convergent and divergent thinking," Front. Human. Neurosci, vol. 7, pp. 824, 2013, https://doi.org/10.3389/fnhum.2013.00824

[31] Colzato, L.S., de Haan, A.M., \& Hommel, B., "Food for creativity: tyrosine promotes deep thinking," Psychol. Res, vol. 79(5), pp. 709-714, 2015, https://doi.org/10.1007/s00426-014-0610-4

[32] Colzato, L. S., Ritter, S. M., \& Steenbergen, L., "Transcutaneous vagus nerve stimulation (tVNS) enhances divergent thinking," Neuropsychologia, vol. 111, pp. 72-76, 2018, https://doi.org/10.1016/j.neuropsychologia.2018.01.003ritter

[33] De Bloom, J., Ritter, S., Kühnel, J., Reinders, J., \& Geurts, S., "Vacation from work: a 'ticket to creativity’? The effects of recreational travel on cognitive flexibility and originality," Tour. Manag, vol. 44, pp. 164-171, 2014, https://doi.org/10.1016/j.tourman.2014.03.013

[34] Ritter, S.M., \& Mostart, N., "Enhancement of creative thinking skills using a cognitivebased creativity training," $J$. Cogn. Enhanc, vol. 1, pp. 10-11, 2016, https://doi.org/10.1007/s41465-016-0002-3

[35] Scott, G., Leritz, L.E., Mumford, M.D., "The effectiveness of creativity training: a quantitative review," Creat. Res $J$, vol. 16, pp. 361-388, 2004, https://doi.org/10.1080/10400410409534549

[36] Zabelina, D.L., \& Robinson, M.D., "Child's play: Facilitating the originality of creative output by a priming manipulation," Psychol. Aesthet. Creat. Arts, vol. 4(1), pp. 57, 2010, https://doi.org/10.1037/a0015644

[37] Jonassen, D., Strobel, J., \& Lee, C.B., "Everyday problem solving in engineering: lessons for engineering educators," J. Eng. Educ, vol. 95(2), pp. 139-151, 2006, https://doi.org/10.1002/j.2168-9830.2006.tb00885.x

[38] Passow, H. J., Passow, C. H., "What competencies should undergraduate engineering programs emphasize? A systematic review," J. Eng. Educ, vol. 106(3), pp. 475-526, 2017, https://doi.org/10.1002/jee.20171

[39] Lynch, M., Kamovich, U., Longva, K. K., \& Steinert, M., "Combining technology and entrepreneurial education through design thinking: Students' reflection on the learning process," Technological Forecasting \& Social Change, 2019. https://doi.org/10.1016/j.techfore.2019.06.015

[40] Rivas, P. G., "Strategies for teaching and dissemination of artistic heritage by promoting critical and creative thinking among future Primary Education teachers," Procedia - Social and Behavioral Science, vol. 237, pp. 717722, 2017. https://doi.org/10.1016/j.sbspro.2017.02.112

[41] Hadzigeorgiou, Y., Fokialis, P., \& Kabouropoulou, "M. Thinking about creativity in science education," Creative Education, 3(05), 603. 2012.

[42] Cramer, D, "Advanced quantitative data analysis," McGraw-Hill Education (UK), 2003.

[43] Creswell, John W., "Educational research: Planning, conducting, and evaluating quantitative and qualitative research," New York: Pearson. 2012.

[44] Kerlinger, F. N., "Foundations of behavioral research," Yogyakarta: Gadjah Mada University Press. 2014.

[45] Cohen, L., Manion, L., \& Morrison, K. Research methods in education: Routledge. 2005.

[46] Piaw, C. Y., "Building a test to assess creative and critical thinking simultaneously," Procedia Social and Behavioral Sciences, 2, 551-559. 2010. https://doi.org/10.1016/j.sbspro.2010.03.062

[47] Ketchabaw, V. P., Kummen, K., \& Thompson, D., "Becoming intimate with developmental knowledge: pedagogical explorations with collective biography," The Alberta Journal of Education Research, 56(3), 335-354. 2010. https://eric.ed.gov/?id=EJ906425 
[48] Ekahitanond, Visara, "Promoting university students' critical thinking skills through peer feedback activity in an online discussion forum," Alberta Journal of Educational Research, 59(2), 247-265. 2013. http://ajer,synergiesprairies.ca/ajer/index.php/ajer/article/view/1088

[49] Rad, I. S., Karimini, L., Ramezani, V., Ahmadi, M., Heshmati, R., \& Jafar, E., "Psychometric properties of Torrance test (Persian version) of creative thinking (A form)," Procedia-Social and Behaviorial Sciences, vol. 5, pp. 1429-1433. 2010. https://doi.org/10.1016/j.sbspro.2010.07.301

[50] Torrance, E. P., "Creativity. What research says to the teacher," Washington, DC: National Education Association. 1969.

[51] Torrance, E. P., "Torrance tests of creative thinking: Norms-technical manual. Bensenville," IL: Scholastic Testing Service, 1974.

[52] Leikin, R., \& Pitta-Pantazi, D., "Creativity and mathematics education: the state of the art," ZDM, 45(2), 159-166. 2013. https://doi.org/10.1007/s11858-012-0459-1

[53] Leikin, R., \& Lev, "M. Mathematical creativity in generally gifted and mathematically excelling adolescents: what makes the difference?," ZDM, vol. 45(2), pp. 183-197, 2013. https://doi.org/10.1007/s11858-012-0460-8

[54] Daher, W., \& Anabousy, A., "Creativity of Pre-service Teachers in Problem Posing." EURASIA Journal of Mathematics, Science and Technology Education, vol. 14(7), pp. 2929-2945. 2018.https://doi.org/10.29333/ejmste/90994

[55] Bai, H., Scoot, C., \& Donal, B., "Contemplative pedagogy and revitalization of teacher education," Alberta Journal of Education Research, vol. 55(3), pp. 319-334. 2009.

[56] Parr, M., \& Campbell, T. A., "Educating for Identity: Problematizing and Deconstructing Our Literacy Pasts," Alberta Journal of educational Research, vol. 57(3), pp. 337-348. 2011. https://eric.ed.gov/?id=EJ950912

[57] Alber, M., "Creative writing and chemistry," Journal of Chemical Education, 78(4), 478-480. 2001 https://doi.org/10.1021/ed078p478

[58] Ramirez, R, P. P., \& Ganaden, M. S., "Creative Activities and Students' Higher Order Thinking Skills," Education Quarterly, vol. 66(1), pp. 22-33, 2008.

[59] Voica, C., \& Singer, F. M., "Problem modification as a tool for detecting cognitive flexibility in school children," ZDM, vol. 45(2), pp. 267-279, 2013. https://doi.org/10.1007/s11858-013-0492-8

[60] Estabrooks, L. B., \& Couch, S. R., "Failure as an active agent in the development of creative and inventive mindsets," Thinking Skills and Creativity, vol. 30, pp. 103-115. 2018. https://doi.org/10.1016/j.tsc.2018.02.015

[61] Kaufman, J.C., Jonathan C. P. \& John B., "Essentials of creativity assessment," John Wiley \& Sons, Inc., Hoboken, New Jersey. 2008.

[62] Scribner, J. P., "The Problems of Practice: Bricolage as a Metaphor for Teachers' Work and Learning," The Albertha Journal of Educational Research, vol. 51(4), pp. 295-310. 2015. https://eric.ed.gov/?id=EJ739639

[63] Richards, J. C., "Creativity in language teaching," Iranian Journal of Language Teaching Research, vol. 1(3), pp. 19-43, 2013. https://files.eric.ed.gov/fulltext/EJ1127396.pdf

[64] Shahrebakbaki, M. M., "Relationships between Language Teachers' Time-management Skills, Creativity, and Burnout: A Mediation Analysis," Alberta Journal of Education Research, vol. 61(1), pp. 20-39. 2015. https://eric.ed.gov/?id=EJ1086497

[65] Piaw, C. Y., "Hindrances to Internal Creative Thinking and Thinking Styles of Malaysian Teacher Trainees in the Specialist Teachers' Training Institute," Procedia Social and Behavioral Sciences, vol. 15, pp. 4013-4018, 2011. https://doi.org/10.1016/j.sbspro.2011.04.406

[66] Mpofu, E., Myambo, K., Mogaji, A. A., Mashego, T.-A., \& Khaleefa, O. H., "African perspectives on creativity," In J. C. Kaufman, \& R. J. Sternberg (Eds.), The international handbook of creativity.Cambridge: Cambridge University Press. 2006.

[67] Humble, S., Dixon, P., \& Mpofu, E., "Factor structure of the Torrance Tests of Creative Thinking Figural Form A in Kiswahili speaking children: Multidimensionality and influences on creative behaviour," Thinking Skills and Creativity, vol. 27, pp. 33-44, 2018. https://doi.org/10.1016/j.tsc.2017.11.005

[68] Lin, Ruilin, "A study of curriculum innovation teaching and creative thinking for picture book creation," IERI Procedia, vol. 2, pp. 30-35, 2012. https://doi.org/10.1016/j.ieri.2012.06.047

[69] Lin, Z. C., "Curriculum and teaching," Kao-Une", Taipei. 2005.

[70] Slahova, A., Savvina, J., Cacka, M., \& Volonte, I., "Creative activity in conception of sustainable development education," International Journal of Sustainability in Higher Education, vol. 8(2), pp. 142-154. 2007. https://doi.org/10.1108/14676370710726616

[71] Chua, Y. P., "Writing a series of best-selling research reference books," Journal of Scholarly Publishing, vol. 40(4), pp. 408-419, 2009. htpps://doi.org/10.3138/jsp.40.4.408

[72] Özcan, A. O., "Algidan yoruma yaratici düsünme," Istanbul: Avciol Basim Yayin. 2000.

[73] Özcan, Deniz, "Contributions of English teachers' behaviours on students' creative thinking abilities," Procedia Social and Behavioral Sciences, vol. 2, pp. 5850-5854, 2010. https://doi.org/10.1016/j.sbspro.2010.03.956 